\title{
脳性麻痺の膝屈曲変形に対する手術小経験
}

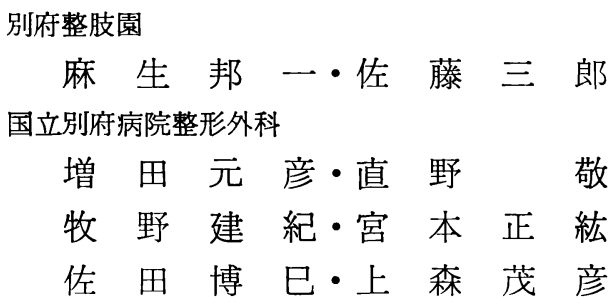

\section{Experience of the Surgery for the Flexion Deformity of the Knee Joint in Cerebral Palsy}

By

\author{
K. Aso \& S. Satoh \\ Beppu Seishien . Hospital \\ M. Masuda, T. Naono, T. Makino, M. Miyamoto, \\ H. Sada \& S. Uemori \\ Beppu National Hospital, Department of Orthopedics
}

\begin{abstract}
We reviewed 16 cases operated between 1967 and 1974 for the knee-flexion deformity in spastic cerebral paralysis.
\end{abstract}

別府整肢園に於いて，C. P. 恣屈曲変形に対し昭和 42 年より 49 年まで, 26 例の手術を行って来たが, 今 回直接検彰しえた 16 例につき検討したので報告する. 16 例の内訳は, 痙直型 15 例 25 膝, 混合型 1 例 2 膝 であり, 手術時年令は 6 才 6 力月から 17 才 1 力, 平均 12 才 1 力月であり, 術後経過期間は 3 力月から 7 年 4 力月, 平均 2 年 4 力月である. 術式別に分類す ると, 膝崫筋解離術, 㬵屈筋移行術, 膝蓋腱前進術, 及び膝屈筋解離術と滕蓋腱前進術との組み合わせ手術 とに大別され, それぞれ I 群, II 群, III群, IV 群とし た. I 群は 4 例 6 膝であり, 切腱, 延長, 腱膜切離, 更には後方関節包切開を加えた例もある. II 群は全て Eggers 変法であり, 半膜様筋を移行したもの 3 例 5 膝, 大腿二頭筋を移行したもの 2 例 2 膝である. III群 は6 例 11 膝と最も多く, 全例 Baker 法もしくはそ の変法である. IN 群は 2 例 3 膝と最も少ない.

術 前 所 見

1) 膝屈曲拘縮の程度について：表の伸展角度は,
完全伸展位を $0^{\circ}$ とし, 反張する場合は $($ 一) として いる. I , II , IV 群は, 全て膝屈筋群の強い緊張があ り，自動伸展で $15^{\circ} \sim 60^{\circ}$ の拘縮を示し，他動でも完 全伸展不能の, いわゆる膝屈筋の短縮を既に起しして いると思われる症例もあった， III群の自動伸展は, 重 力に抗して伸展しうる角度を測定したものであり, 全 例独力では完全伸展が不能であったが, 他動的には完 全伸展が容易であった。

2) 下肢運動機能について：表の○は独力で可能, $\triangle$ \は支助にて可能, ×は不可能を表示したものだが， 全例既に立位バランスは確立されており, 症例 4,5 を除き下肢の交互性もよいものであった.

3) 合併手術について：1例を除いた 15 例が, 凌 変形に対する手術より前に，あるいは同時に股関節及 び足関節の変形に対し，何らかの矯正手術が施されて いた。

\section{術 後 所 見}

1) 膝屈曲変形の改善と拘縮の再発について : 屈曲 
表 1 PREOPERATIVE STATUS

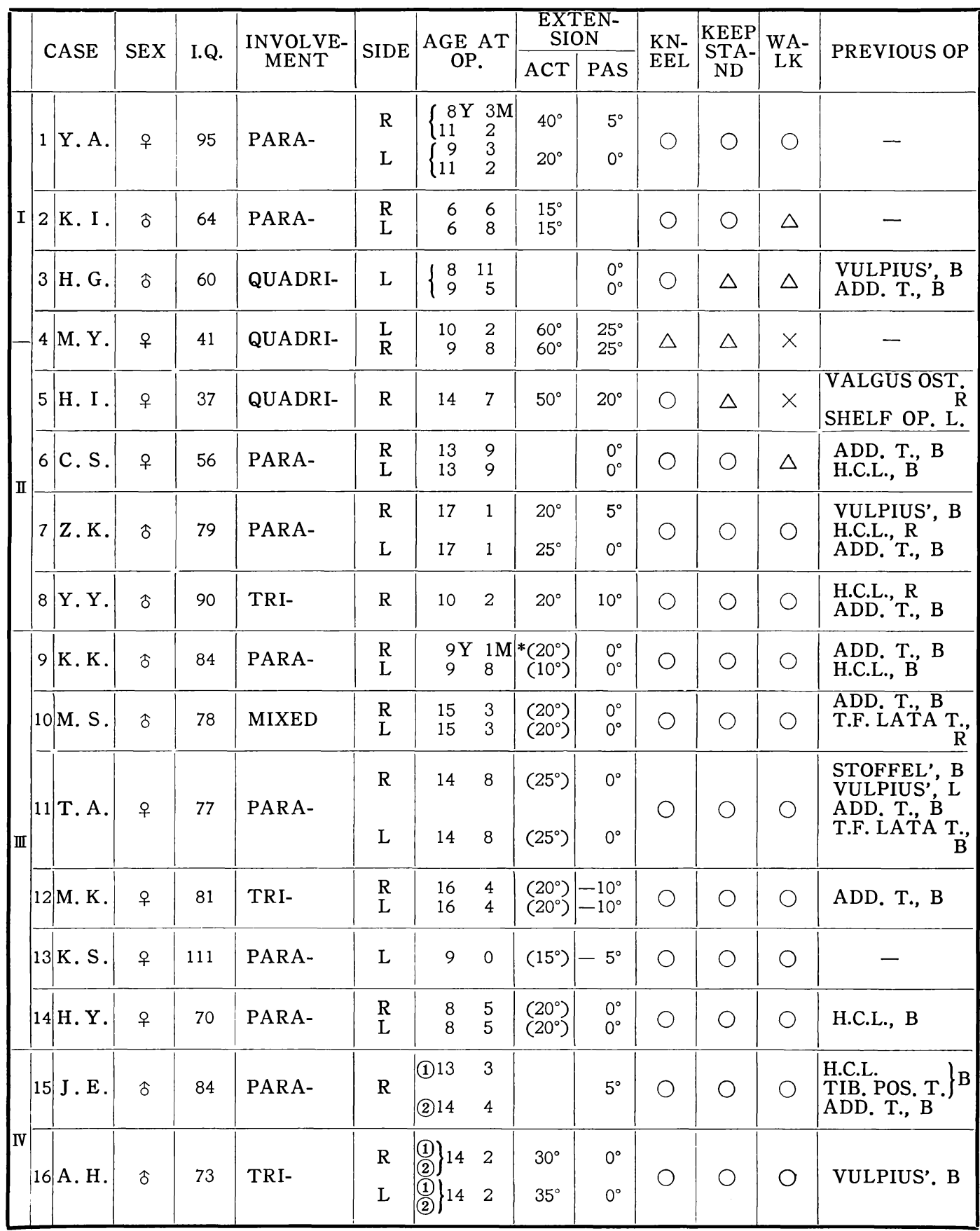

（注） B：両側，ADD. T.：内転筋切離，H.C.L.：アキレス腱延長 
脳性麻㿉の膝届曲変形に対する手術小経験

表 2 POSTPERATIVE STATUS

\begin{tabular}{|c|c|c|c|c|c|c|c|c|c|c|c|}
\hline \multirow{2}{*}{$\left|\begin{array}{l}|r| r \mid \\
0 \\
0 \\
0\end{array}\right|$} & 玨 & \multirow{2}{*}{\multicolumn{2}{|c|}{$\underset{\text { UP }}{\text { FOLLOW }}$}} & \multirow{2}{*}{ TECHNIQUE } & \multicolumn{2}{|c|}{$\begin{array}{l}\text { EXTEN- } \\
\text { SION }\end{array}$} & \multirow{2}{*}{$\begin{array}{l}\text { 再 } \\
\text { 発 }\end{array}$} & \multirow{2}{*}{$\left|\begin{array}{l}\text { 反 } \\
\text { 脹 } \\
\text { 膝 }\end{array}\right|$} & \multicolumn{2}{|c|}{\begin{tabular}{|c|} 
MUSCLE \\
STRENGTH
\end{tabular}} & \multirow{2}{*}{$\begin{array}{l}\text { ADDITIONAL } \\
\text { OP }\end{array}$} \\
\hline & के & & & & ACT & PAS & & & $\begin{array}{l}\text { FLEX. } \\
\text { (kg) }\end{array}$ & $\begin{array}{l}\mathrm{FXT} \\
(\mathrm{kg})\end{array}$ & \\
\hline 1 & R & & $\begin{array}{l}1 \mathrm{M} \\
1\end{array}$ & $\begin{array}{l}\text { (1)B.F. } \\
\text { (2)GR, S-T, S-M : LENG. } \\
\text { (1)B.F., S-M, S-T : TEN. } \\
\text { (2)GR, S-M, S-T: TEN. }\end{array}$ & $\begin{array}{l}0^{\circ} \\
0^{\circ}\end{array}$ & $\begin{array}{l}-10^{\circ} \\
-5^{\circ}\end{array}$ & $\begin{array}{l}*(+) \\
(+)\end{array}$ & \pm & $\begin{array}{l}0.5 \\
1.0\end{array}$ & $\begin{array}{l}5 \\
6\end{array}$ & $\begin{array}{l}\text { TEN. FAS. LT., B } \\
\text { ADD. T., B }\end{array}$ \\
\hline$I^{2}$ & R & 5 & $\begin{array}{r}10 \\
8\end{array}$ & $\begin{array}{l}\text { S-T: LEN. } \\
\text { S-M : TEN. POS. CAPS. } \\
\text { S-T, GR. } \\
\text { SAR.\} TEN.S-M B. R. }\} \text { LEN. }\end{array}$ & $\begin{array}{l}0^{\circ} \\
0^{\circ}\end{array}$ & $\begin{array}{l}-10^{\circ} \\
-10^{\circ}\end{array}$ & & $\begin{array}{l}+ \\
+\end{array}$ & $\begin{array}{l}1 \\
2.5\end{array}$ & $\begin{array}{l}14 \\
14\end{array}$ & $\begin{array}{l}\text { H.C.L., B } \\
\text { ADD. T., B }\end{array}$ \\
\hline 3 & $\mathrm{~L}$ & 3 & 5 & $\begin{array}{l}\text { (1)B. F. : LEN. } \\
\text { (2)S-T.GR \}: TEN. } \\
\text { S-M. }\end{array}$ & $0^{\circ}$ & $-15^{\circ}$ & $(+)$ & + & 2 & 9.5 & H.C.L., B \\
\hline 4 & L & 4 & $\begin{array}{l}6 \\
0\end{array}$ & $\begin{array}{c}\text { S-T : TEN., S-M } \\
\text { B-F }\} \text { LEN. } \\
\text { B.F.: TRAN., GR: TEN. } \\
\text { S-T : LEN. } \\
\text { S-M : APON. DIV. }\end{array}$ & $22^{\circ}$ & $10^{\circ}$ & + & 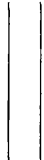 & 0 & $\begin{array}{l}10.5 \\
12\end{array}$ & $\begin{array}{l}\text { H.C.L., B } \\
\text { ADD. T., B }\end{array}$ \\
\hline 5 & $\mathrm{R}$ & 7 & 4 & B.F.: TRAN, $\left.\begin{array}{r}\text { S-T } \\
\text { S-M }\end{array}\right\}$ TEN. & $20^{\circ}$ & $10^{\circ}$ & + & & 1 & 6 & $\begin{array}{l}\text { H.C.L., B } \\
\text { ADD. T., L }\end{array}$ \\
\hline II ${ }^{6}$ & $\begin{array}{l}\mathrm{R} \\
\mathrm{L}\end{array}$ & & $\begin{array}{l}11 \\
11\end{array}$ & $\begin{array}{l}\text { S-M : TRANS. } \\
\text { B.F.: APON. DIV. GR }\}_{\text {SUUT. }}^{\text {TEN. }}\end{array}$ & $\begin{array}{l}0^{\circ} \\
0^{\circ}\end{array}$ & $\begin{array}{l}0^{\circ} \\
0^{\circ}\end{array}$ & & & $\begin{array}{l}0 \\
0\end{array}$ & $\begin{array}{l}12 \\
13.5\end{array}$ & - \\
\hline 7 & $\mid \begin{array}{l}\mathrm{R} \\
\mathrm{L}\end{array}$ & & $\begin{array}{l}11 \\
11\end{array}$ & " & $\begin{array}{l}5^{\circ} \\
0^{\circ}\end{array}$ & $\begin{array}{l}0^{\circ} \\
0^{\circ}\end{array}$ & & & & & $\begin{array}{l}\text { HIP FLEX. R., B } \\
\ldots \ldots \ldots \ldots . . .\end{array}$ \\
\hline 8 & B & & 7 & $\begin{array}{l}\text { S-M : TRANS. } \\
\text { S-T } \\
\text { GR }\} \text { TEN. \& SUTURED }\end{array}$ & $5^{\circ}$ & $0^{\circ}$ & & & 2 & 8 & - \\
\hline s & $\mid \begin{array}{l}R \\
L\end{array}$ & $1 \mathrm{Y}$ & $\begin{array}{l}3 \mathrm{M} \\
8\end{array}$ & $\begin{array}{l}\text { BAKER' } \\
\text { BAKER' (MOD.) }\end{array}$ & $\begin{array}{l}0^{\circ} \\
0^{\circ}\end{array}$ & $\begin{array}{l}-10^{\circ} \\
-10^{\circ} \\
\end{array}$ & & + & $\begin{array}{l}3 \\
2 \\
\end{array}$ & $\begin{array}{c}10 \\
9.5\end{array}$ & - \\
\hline 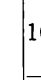 & $0 \begin{array}{l}R \\
L\end{array}$ & & $\begin{array}{l}8 \\
8\end{array}$ & $\begin{array}{c}\text { BAKER' } \\
" \prime\end{array}$ & $\begin{array}{l}0^{\circ} \\
0^{\circ}\end{array}$ & $\begin{array}{l}-5^{\circ} \\
-5^{\circ}\end{array}$ & & \pm & $\begin{array}{l}8 \\
7.5\end{array}$ & $\begin{array}{l}12.5 \\
12.5\end{array}$ & - \\
\hline 1 & $1 / \mathrm{R}$ & & $\begin{array}{l}7 \\
7\end{array}$ & $\begin{array}{c}\text { BAKER' } \\
\prime \prime\end{array}$ & $\begin{array}{l}0^{\circ} \\
0^{\circ}\end{array}$ & $\begin{array}{l}0^{\circ} \\
0^{\circ}\end{array}$ & & & $\begin{array}{l}2.5 \\
2.5\end{array}$ & $\begin{array}{l}12 \\
14\end{array}$ & - \\
\hline $\mathbf{m}$ & $2 \mid \begin{array}{l}\mathrm{R} \\
\mathrm{L}\end{array}$ & & $\begin{array}{l}7 \\
7\end{array}$ & $\begin{array}{c}\text { BAKER' } \\
" \prime\end{array}$ & $\begin{array}{l}0^{\circ} \\
0^{\circ} \\
\end{array}$ & $\begin{array}{l}-10^{\circ} \\
-10^{\circ} \\
\end{array}$ & & $|+|$ & $\begin{array}{l}1 \\
0\end{array}$ & $\begin{array}{l}15 \\
15.5\end{array}$ & - \\
\hline 1 & $3 \mathrm{~L}$ & & 4 & BAKER' & $0^{\circ}$ & $-12^{\circ}$ & & + & 3 & 6 & ADD. T., B \\
\hline 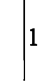 & $4 \mid \begin{array}{l}\mathrm{R} \\
\mathrm{L}\end{array}$ & & $\begin{array}{l}3 \\
3\end{array}$ & $\begin{array}{l}\text { BAKER' (MOD.) } \\
\text { BAKER' }\end{array}$ & $\begin{array}{l}5^{\circ} \\
5^{\circ}\end{array}$ & $\begin{array}{l}0^{\circ} \\
0^{\circ}\end{array}$ & & & $\begin{array}{l}4 \\
3.5\end{array}$ & 10.5 & - \\
\hline 1 & $5 R$ & 1 & 2 & $\left\{\begin{array}{l}\text { (1) S-T. S-M, GR. } \\
\text { B.F. } \\
\text { (2)BAKER' }\end{array}\right.$ & $0^{\circ}$ & $0^{\circ}$ & & & 0.5 & 14 & $\begin{array}{l}\text { G-G OP., B } \\
\text { McBRIDE' OP,, B }\end{array}$ \\
\hline IV & $\left.6\right|^{R}$ & & 8 & $\begin{array}{l}\left\{\begin{array}{l}\text { (1) S-T } \\
\text { S-M }\end{array}\right\} \text { LENG., } \begin{array}{l}\text { GR }: \text { TEN } \\
\text { B.F. APN. } \\
\text { DIV. } \\
\text { (2)BAKER' (MOD.) }\end{array} \\
\left\{\begin{array}{l}\text { (1)S-T. S-M : } \\
\text { LENG. GR : } \\
\text { (2)BAKER, }\end{array}\right.\end{array}$ & $0^{\circ}$ & $\mid \begin{array}{l}-20^{\circ} \\
-20^{\circ}\end{array}$ & & $H$ & $\begin{array}{l}0.5 \\
0.5\end{array}$ & 11 & - \\
\hline
\end{tabular}

（注） B.F.=Biceps fomoris, GR.=Gracilis, S-T=Semi tendinosus, S-M=Semi membranosus, MOD.=Modified, APON. DIV.=Aponeurotic division 


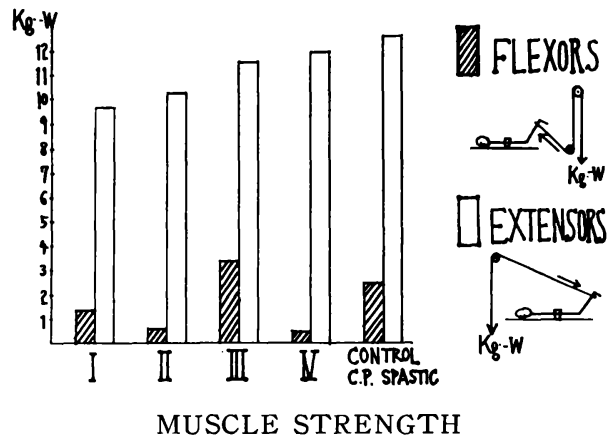

変形の改善は, 12 例 21 膝の 8 割にみられ, 膝蓝腱を 前進させた III， $\mathrm{N}$ 群では，1例を除き全例が重力に抗 して完全伸展が可能となった。一方，I，II群の 4 例 6 膝が拘縮を再発しており，中でも I 群は 3 例 4 膝と 大部分を占める.

2 ）反張滕について：術後反張膝の発生をみたもの は，8例 14 膝に上り，特に I 群と吕群に集中してい る.

3）筋力について：図の如き装置と計測方法を用 い, 手術群及び非手術群として 17 例 25 膝の疘直型 C. P. 児を選び，その筋力を測定した。 その結果，膝 屈筋を処理した I， II，N群の屈笳力の低下は著し く,徒手筋力テストにても全例 [3-]以下, 平均 [2.0] であった．伸筋力では，術前伸筋力の弱化が予想さ れ，膝蓋腱前術を施行したIII， IV 群が，術後は逆に I， II 群を上回っている.しかしながら，同一症例に つき，その術前後を比較した訳ではないので，筋力評 価には一定の限界があるのは止むを得ない。

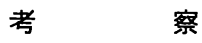

I 群の膝屈筋解離術は，術式が一定せず，また症例 数も少なく，結論は出せないが，今回われわれの調査 例では，再拘縮や反張膝の発生が最も目立った。その 内 2 例 2 㮏は共に, 大腿二頭筋のみを延長したもので ある．Eggers 法を行ったII 群では，大避二頭筋を移 行した 2 例 2 滕が共に拘縮を再発しており, 半膜様筋 を移行し,薄筋・半腱样筋は切腱し移行筋に縫着し,大 腿二頭筋は温存するか，もし、は，腱膜切離にとどめ た例は，再拘縮や反張膝の発生はみられなかった．膝 屈曲拘縮における原因筋として，内側ハムストリング の役割が大きいととがうかがわれる，滕蓋腱前進術は 最も多く， III， N 群あわせて 8 例 14 滕になされた
変形, 反張䐝がない, 比較的年長児には適応があり， その効果も期待できるものと思われる.

そこで, 膝蓋骨の高さについて, 本手術群と I - II 群，C. P. 群及び正常群とで，大腿骨下端から膝蓋骨 の中心までの距髉を測定し，比較検討してみた。 そ の結果, III-IV群は正常群に比べてはやや高いが, C. P. 群と比べると有意の差はみられなかった．また 術前・術後の膝蓋骨の高さを比較してみると, 術中 $2 \sim 3.5 \mathrm{~cm}$ 膝蓋腱を前進させたにも拘わらず，膝蓋 骨はわずか平均 $1.6 \mathrm{~cm}$ しか下降がなく，やはり膝 蓋腱の伸張があったものと推察された，術後は全例に おいて, 膝屈曲位歩行は消失し, 重力に抗しても完全 伸展が可能となり，歩行能力も向上した．しかしなが ら逆に，弾性を欠いた痙性の棒足歩行，駆幹の前傾・ 動摇を呈して, 決して歩容が改善したとは思われない 症例も 3 例あった。 また反張膝か認められるのは 5 例 9 膝, 約 $2 / 3$ の高率に上り, 内 2 例は術前加ら存在し ていた軽度の反張滕が術後増強し, 決定的となったも のである．また術前多少とも存在していた股屈曲変形 が著明になり, 骨盤の前傾が目立って来た症例が 4 例 あった，反張膝及び股屈曲変形は術前十分慎重に検索 せねばならないと反省している．また完全伸展が可能 となり, 歩行能力が向上したとは言え, 逆に膝屈曲障 害が招来され，全例きちんとした正坐は不可能となっ た. 特に年頃の女子では, 膝前面の手術疲痕による美 容上の問題と共に，正坐ができないということは大き な䦓題であり,適応には慎重を要するものと思われる。

\section{結語}

16 例の C. P. 膝屈曲変形手術例につき, 術式別に 比較検討した結果，次の如き知見得た。

1）膝屈曲拘縮には, 内側ハムストリングの関与が 大であり，てれに対し適当な処理を加えないと，術後 再拘縮を来たし易い.

2 ）しかし一方, 膝屈筋を処理した群式では, 術後 楚屈筋力の低下が著明であり, 術後反張膝の発生も多 い. 大腿二頭筋は温存するか延長して, 屈曲力を残し た方がよいように思う。

3 ）半膜様筋を移行する Eggers 変法は, 再拘縮 反張膝の発生からみて, 最も秀れていた。

4) 膝蓋腱前進術は, 滕蓋腱の伸張があり, 股屈曲 本手術は, 膝蓋腱の伸張がある状態, 即ち立位や歩行 にて 膝屈曲位をとり, 重力に抗して 伸展が $10^{\circ} \sim 20^{\circ}$ 
にとどまり,一方膝屈筋の強い緊張はなく,しかも滕蓋 骨の位置が高い状態のものには，適応があると考える.

（発表を終るに際し，御協力を頂いた別府整肢園の O. T., P. T., ナース及び職員の皆椂方に心から感謝 申し.上げます。）

\section{文献}

1）伊藤鉄夫：臨床整形外科全書. 5,379 , 東京.

2) Eggers, G. W. N.: J. B. J. S. 34-A, 827, 1952.

3) Baker, L. D.: J. B. J.S. 38-A, 313, 1956.

4) Roberts, W. M.: J.B.J.S. 35-A, 958, 1953.

5) Keats, S.: J.B.J.S. 44-A, 1146, 1962.

6) Eggers, G. W. N.: J. B. J. S. 45-A, 1275, 1963.

7）Keats, S. (高松, 国定訳).：脳性麻㾝の整形 外科手術. 医菌薬出版, 東京, 1973.

8）深瀬宏：臨整外. 8, 651, 1973.

9）潹瀬 宏: 臨整外. 3, 173, 1968.

\section{犋問新日鉄八幡製鉄所病院 碓井 良弘}

(1) Patellar ligament の前進術をした例に屈曲拘 縮の改善は出来ているが, 屈曲障害を起てしている.

Retinaculum patellae の緊張のために Lig. patellae の機能不全が起こるといわれているが，実際手 術の適応を決める時どのようにするのか.

\section{罂問, 意見足立学園 安藤 忠}

(1) われわれは，完全伸展を得ようとは思っていな い, 従って, 褝屈曲拘縮の矯正術においては, 内側屈 筋群のみに侵襲を加えて, 外側屈筋群は, つとめて温 存している.

てれについては，演者はいかがお考えか。

(2) 脐は，下肢の一部分にすぎず，乙の部位の侵襲 は, 上下関節（股, 足関節）飞多少とも機能的, 器質 的に影響を与えると思うが，ての点について御教示い ただきたい。

回 答 別府整肢園 麻生 邦一

1 ）碓井先生の御質問に対する回答：
Eggers が述べている, Patellar Retinacula を切 離することにより，Quadriceps の伸展力が Tibia に十分伝達されるという原理は, 自動伸展が $10^{\circ}$ 前後 の軽度のものでは適応とされるが, 自動伸展で $20^{\circ}$ 以 下にとどまり，また明らかに膝蓋腱の伸張，Patella の高位などがあれば, Retinacula を切るのみなら ず, Patellar Tendon を前進させる方が Merit は大 きいものと考えます.

2 ) 安藤先生の質問に対する回答:

(1)御膝屈曲変形が矯正され, 㮏関節の伸展力が増強 したために，機能的にも歩行能の向上，例えば走れる ようになったとか, 歩行速度が増したとか，椅子から の立ち上がりが容易になったなど, 歩容の改善と共に その機能的効果が一定評価された症例が多く, 適応を 慎重に考虑すれば，その手術効果は期待できるものと 考えます。

(2) われわれも同じく, まず股関節, 足関節の変形 を矯正し, 一定期間観察して後, 膝関節变形に対し手 術を加えることを原則としている。

(3) われわれの Eggers 変法群の症例でも, Biceps Femorts を温存するか，または腱膜切離にとどめ た術式が秀れた成績を残している.

翼 問 福岡日赤病院 徳永 純一

(1) 術後の反張膝予防のために術前にどのように考 えているか.

(2) 完全伸展については足立学園の安藤先生の云う ように完全伸展を期待せずに，屈曲力を残す方がよい と考える。

回 答 別府整肢園 麻生 邦一

3 ) 徳永先生の御質問に対する回答 :

C. P. の術前の臨床的筋力評価は困難であり, 滕蓋 腱前進の度合も確かな量的基準をもちえない。

前進術後, 反張滕の発生が多いので, 前進は Campbell が述べている 11/2 Inch よりも控え目に行って いる. 